\title{
Body lifting, flattening, and burying of Tropidurus catalanensis Gudynas \& Skuk, 1983 (Squamata, Tropiduridae): Defense, thermoregulation, or both?
}

\section{Thiago Maia-Carneiro* and Carlos Arturo Navas}

Universidade de São Paulo. Departamento de Fisiologia. Laboratório de Ecofisiologia e Fisiologia Evolutiva. Rua do Matão, 321, Travessa 14. São Paulo-SP, Brazil (CEP 05508090).*Email: tmaiacarneiro@gmail.com.

\begin{abstract}
Lizards of the genus Tropidurus display different behaviors for thermoregulation and defense. Here, we report new displays for Tropidurus catalanensis, which helps to understand how these lizards behave. Captive individuals lifted, flattened, and buried their bodies. Flattening and upstanding the bodies allow looking larger and may discourage attacks, as well as respectively enhance and decrease the approximation and the contact of body surfaces with substrates to thermoregulate. Burying themselves into earth and sand may help lizards to avoid or escape from menaces. When we first opened the containers, the T. catalanensis were already partially covered by vermiculite, which did not allow stating if they did it in response to supposed risks of predation because perceived the movements in the room or were already buried. Tropidurus catalanensis possibly may bury themselves to avoid detection during periods of inactivity. The self-burying behavior may be useful also for thermoregulation using substrate temperatures. Tropidurus catalanensis may increase the chances of getting out safe from dangerous interactions and of effective thermoregulation by performing such behaviors. Although we discussed the behaviors on the views of defense and thermoregulation, the body lifting, the flattening, and the burying seemed have occurred in a defensive context.
\end{abstract}

$\begin{array}{lccc}\text { Keywords: } & \text { Behavior; Defensive behavior; } & \text { Defensive } \\ \text { mechanisms; } & \text { Self-burying; } & \text { Thermoregulatory } & \text { behavior; } \\ \text { Tropidurinae. } & & & \end{array}$

Received

October 20, 2020

Accepted

November 30, 2020

Released

December 31, 2020

Full Text Article

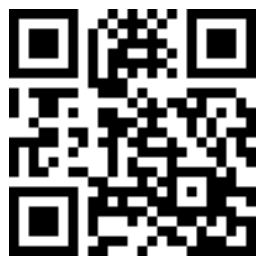

ORCID
0000-0002-9217-8783
Thiago Maia-Carneiro
(1) 0000-0002-9859-0568
Carlos Arturo Navas

Lizards of the genus Tropidurus display different behaviors for thermoregulation and defense (Machado et al., 2007; Nunes et al., 2012; Maia-Carneiro and Rocha, 2015, 2017, 2020a, b; Maia-Carneiro et al., 2020), as so Tropidurus catalanensis, which controls body temperatures using substrate temperatures (see Maia-Carneiro and Navas, 2021) and performs immobility, locomotor escape by running and climbing, squirreling, tail waving, tail lifting, mouth opening, forced escape, and cloacal discharge (Maia-Carneiro et al., 2020). Here, we report behaviors not yet known for T. catalanensis, which helps to

ISSN 2358-2731/BJBS-2020-0056/2020/7/17/9/339 
understand how these lizards thermoregulate and evade potentially harmful interactions. The individuals were held in captivity in a climatic room with controlled temperatures during 2018 in the Laboratory of Ecophysiology and Evolutionary Physiology of the São Paulo University, Municipality of São Paulo, State of São Paulo, Brazil, where they lifted, flattened, and buried their bodies. Body flattening is common in lizards that hide into narrow rock crevices to avoid or escape from threats (Cooper and Blumstein, 2015). Nevertheless, as T. catalanensis remained in sight when flattening and upstanding their bodies, they may have done that not to conceal themselves, but to look larger and discourage attacks. As well, flattening and upstanding the bodies allow respectively enhance and decrease the approximation and the contact of body surfaces with substrates to thermoregulate. Burying themselves into earth and sand may help lizards to avoid or escape from menaces (Rocha et al., 2002; Maia-Carneiro and Rocha 2013; Cooper and Blumstein, 2015). As an example, inactive Tropidurus torquatus commonly buried themselves into earth (Rocha et al., 2002). When we first opened the containers, the T. catalanensis were already partially covered by vermiculite (Figure 1), which did not allow stating if they did it in response to potential risks of predation because perceived the movements in the room or were already buried. Perhaps as T. torquatus (Rocha et al., 2002), T. catalanensis bury themselves to avoid detection during periods of inactivity. The self-burying behavior may be useful also for thermoregulation using substrate temperatures (Rocha et al., 2009; Maia-Carneiro and Rocha, 2020a; Maia-Carneiro and Navas, 2021). Tropidurus catalanensis may increase the chances of getting out safe from dangerous interactions and of effective thermoregulation by performing such behaviors. Although we discussed the behaviors on the views of defense and thermoregulation, the body lifting, the flattening, and the burying seemed have occurred in a defensive context.

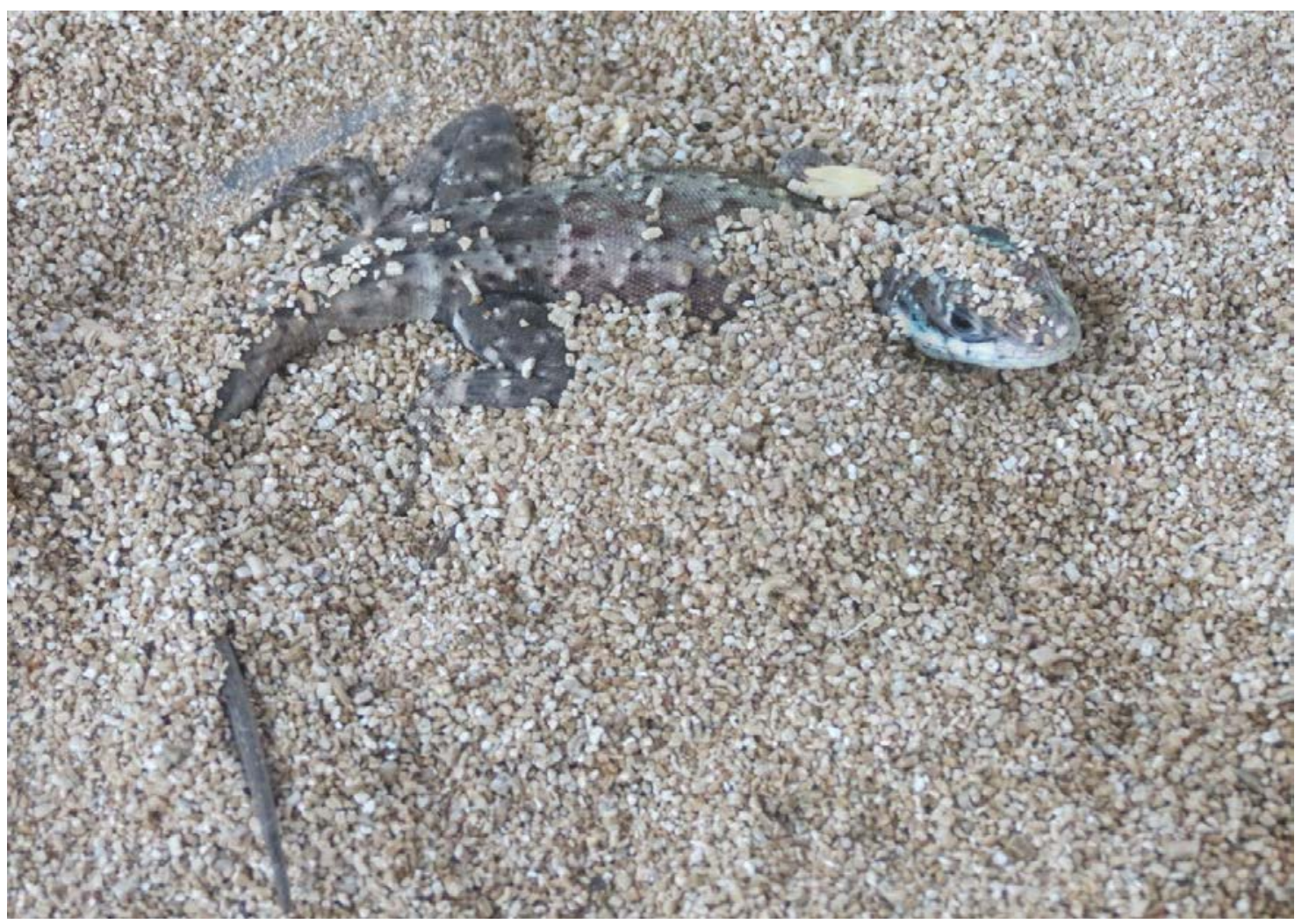

Figure 1. Tropidurus catalanensis buried under vermiculite. The individuals varied in the portion of the bodies they covered at different occasions they repeated the behavior. 


\section{Acknowledgements}

We are grateful to the Coordenação de Aperfeiçoamento de Pessoal de Nível Superior (CAPES) and the Fundação de Amparo à Pesquisa do Estado de São Paulo (FAPESP; São Paulo Research Foundation) for a grant to TMC and for financing the research (process $\left.n^{\circ} 2016 / 23599-3\right)$. This process is linked to the thematic research project "Impacts of climate/environmental change on the fauna: An integrative approach" (process no 2014/16320-7; Technological Innovation Programs/PFPMCG - FAPESP Program for Research on Global Climate Change/PFPMCG), for which we are also grateful.

\section{Conflict of interest}

The authors declare that they have no conflict of interest.

\section{References}

Cooper, W. E., Jr.; Blumstein, D. T. Escaping from predators: An integrative view of escape decisions. Cambridge: Cambridge University Press, 2015.

Machado, L. L.; Galdino, C. A. B.; Sousa, B. M. Defensive behavior of the lizard Tropidurus montanus (Tropiduridae): Effects of sex, body size and social context. South American Journal of Herpetology, v. 2, p. 136-140, 2007. https://doi.org/10.2994/18089798(2007)2[136:DBOTLT]2.0.CO;2

Maia-Carneiro, T.; Langie-Santos, S.; Navas, C. A. Defensive behaviors of Tropidurus catalanensis Gudynas \& Skuk, 1983 (Squamata, Tropiduridae). Brazilian Journal of Biological Sciences, v. 7, no. 15, p. 39-42, 2020. https://doi.org/10.21472/ bjbs(2020)071504

Maia-Carneiro, T.; Navas, C. A., Ecological constraints to match field and preferred temperatures in lizards Tropidurus catalanensis (Squamata; Tropiduridae). Journal of Thermal Biology, v. 98, 102903, 2021. https://doi.org/10.1016/j.jtherbio.2021.102903

Maia-Carneiro, T.; Rocha, C. F. D. Diverging temporal and thermal niche dimension favor syntopy of Tropidurus hispidus and Tropidurus semitaeniatus (Squamata: Tropiduridae). Biologia, v. 76, p. 133-146, 2020a. https://doi.org/10.2478/s11756-020-00523-w

Maia-Carneiro, T.; Rocha, C. F. D. Flight initiation distances of Tropidurus hispidus and Tropidurus seitaeniatus (Squamata, Tropiduridae) in sympatry. Herpetological Conservation and Biology, v. 10, n. 2, p. 661-665, 2015.

Maia-Carneiro, T.; Rocha, C. F. D. The behaviour of orientation of openings of burrows by Liolaemus lutzae (Squamata: Liolaemidae): Is it influenced by environmental factors? Journal of Natural History, v. 47, n. 3/4, p. 253-262, 2013. https://doi.org/10.1080/ 00222933.2012 .743612

Maia-Carneiro, T.; Rocha, C. F. D. Tropidurus hispidus (Lagartixa; Peters' Lava Lizard) and Tropidurus semitaeniatus (calango-de-lajedo). Clocal discharge. Herpetological Review, v. 51, n. 2, p. 336-337, 2020b.

Maia-Carneiro, T.; Rocha, C. F. D. Tropidurus hispidus (Peters' Lava lizard). Antipredator mechanisms. Herpetological Review, v. 48, n. 2, p. 441-442, 2017.

Nunes, J.V.; Elisei, T.; Sousa, B. M. Anti-predator behaviour in the Brazilian lizard Tropidurus itambere (Tropiduridae) on a rocky outcrop. Herpetological Bulletin, v. 120, p. 22-28, 2012. 
Rocha, C. F. D.; Dutra, G. F.; Vrcibradic, D.; Menezes, V. A. The terrestrial reptile fauna of the Abrolhos Archipelago: Species list and ecological aspects. Brazilian Journal of Biology, v. 62, n. 2, p. 285-291, 2002. https://doi.org/10.1590/S1519-69842002000200013

Rocha, C. F. D.; Van Sluys, M.; Vrcibradic, D.; Kiefer, M. C.; Menezes, V. A.; Siqueira, C. C. Comportamento de termorregulação de lagartos brasileiros. Oecologia Brasiliensis, v. 13, p. 115-131, 2009.

License information: This is an open-access article distributed under the terms of the Creative Commons Attribution License, which permits unrestricted use, distribution, and reproduction in any medium, provided the original work is properly cited. 